\title{
Investigation of the Interactions of Mothers and Their 30-42 Months Old Children who are Living in Different Family Types in the Context of Mother Sensitivity \\ Zeynep Deniz SEVEN ${ }^{1}$, Erhan ALABAY
}

ARTICLE INFO

Article History:

Received 03.03.2019

Received in revised form

26.12.2019

Accepted

Available online 01.01.2020

\begin{abstract}
This study was conducted to investigate the interactions of mothers and 30-42 months old children living in large and nuclear family types in the context of maternal sensitivity. In this study, one of the qualitative research methods, embedded multi-case research was used. The participants of the study consisted of 8 mothers living in 4 large- 4 nuclear family types and their children aged 30-42 months in the town of Muş. Descriptive-interpretive data analysis was used to describe the interactions of the studied group in depth by using natural and structured observation, mother-child information form and mother-child observation form. It was observed that children send their messages verbally, mothers' reactions are mostly positive in the extended family, mostly in the negative nuclear family, and mothers of both family types exhibit very limited behaviors in showing and sharing their feelings, showing cooperation and coordination behaviors, physical contact and eye contact. It is thought that mothers who have moved from extended families to nuclear families have predominantly extended family behavior patterns in these respects.
\end{abstract}

C IJERE. All rights reserved

Keywords:

Attachment, maternal sensitivity, Emotional Availability, Interactional Synchrony, family type.

\section{INTRODUCTION}

Attachment refers to a structure that goes beyond defining a relationship that is shaped by looking for the secure and protection behaviors of certain people when we feel anxious and insecure (Cassidy, 2016). John Bowlby defines attachment as a fundamental need with biological origins. According to him, attachment is a continuous emotional bond against a particular figure that tends to seek and maintain closeness in stressful situations (Bowlby, 1969; p.194). Ainsworth et al. (1978) mention that attachment is a bond that mediates subsequent relationship experiences.

Attachment behavior (usually the mother) is predictable behavior based on seeking closeness to the attachment figure. The baby requests interaction by sending messages to the mother about their needs. The mother's efforts to meet these demands constitute the quality of attachment (Cassidy, 2016).

Ainsworth has succeeded in transforming Bowlby's theoretical views into measurable through applied research. Ainsworth's "strange situation "method has become an important milestone for attachment research (Cassidy, 2016). Based on the data obtained by this method, Ainsworth et al. 1dentified three basic types of attachment (Ainsworth et al., 1978): Secure attachment, ambivalent/ resistant-insecure attachment and avoidance-insecure attachment. However, the type of attachment known as nonorganizedinsecure attachment was added by Main and Solomon (Main and Solomon, 1990) to the attachment classification as the fourth type.

Bowlby argued that Jean Piaget was influenced by the concept of the Schema and structured in his mind an internal working model that gave clues about individuals' own behavior in relationships. According to the internal working model, the interactions with the attachment figure become internalized in the baby's mind and form a model. This model actually comes from the tendency to relax by predicting the behavior of the baby's attachment figure. Over time, this internal model begins to function as an unconscious entity and determines the direction of their responses to cognitive engagement (Wallin, 2007). As the child grows up, this working model guides social relationships.

The internal working model begins to develop within a few months of birth. It is constructed as a result of the baby's relationship with the attachment figure. Thus, the baby reacts to the newly encountered individuals according to this model. The model is dynamic. The new information is combined with the old information. If the attachment figure changes its behavior, the internal working model assimilates it. However, the new experiences assimilated cannot completely change the model. In this case, the child will have some conflicting models against the attachment figure (Holmes, 2014).

The sensitivity of the attachment figure and the attitudes towards the child are important in establishing the internal working model (Eagle, 2013). When he conveys verbal-non-verbal messages related to the needs of

${ }^{1}$ Corresponding e-mail: denizzeynepseven@hotmail.com, orcid.org/0000-0003-3900-989X

İstanbul Esenyurt University , Sağlık Bilimleri Üniversity² 
the child to his mother, he receives a response to the message, whether the response he receives is positive or negative, and interactions about whether he meets his needs in time form the structure of the internal working model.

Scientists who form the theoretical framework of attachment have strongly incorporated maternal sensitivity in the cues sent by the baby in developing a secure infant-mother attachment relationship (Bowlby, 1969). Ainsworth and colleagues (Ainsworth et al., 1978) developed various scales to assess maternal sensitivity and attachment. As a result of the studies conducted with these scales, it was found that the sensitivity history of the mother was related to the quality of attachment (Smith \& Pederson, 1988)

Maternal sensitivity is seen as a key factor in mother-child interaction (Vereijken and Riksen-Walraven, 1997). Sensitivity is defined by Ainsworth et al. (Ainsworth, Bell and Stayton, 1974; p.127) as the ability to correctly perceive and interpret the signals and communication demands of the infant's behavior and to respond quickly and appropriately with this way. It is thought that sensitive mothers give the interaction experiences they need to develop a sense of security to their babies in the mother-child relationship (Vereijken \& Riksen-Walraven, 1997).

In addition to responding to the protection and love needs of a baby or child, sensitivity includes conceptualization on Mary Ainsworth's scales, respect for the child as a valuable person with autonomic emotions, needs, desires, goals and his own mental structure. The sensitive behaviors of the child's caregiver mean that his or her communication efforts are understood, considered remarkable and responded quickly and appropriately. In addition, the mother's responsive responses have been shown to promote the child's competence (Grossman, Bretherton, Waters, \& Grossman, 2016).

There are basically five dimensions of mothers' parenting behaviors that are examined by developmental psychologists in the context of attachment: These are the sensitivity cycle, sensory sensitivity, Emotional Avaliability, Interactional Synchrony, and recently popularized Mind-mindedness.

The mother's care and care for her child may vary depending on the type of family, the rules of the family and the number of individuals living in the family. Considering the upbringing of children by traditional rules, it is seen that mothers in large families are less predictable than mothers in nuclear families. Similarly, the relationship between attachment and maternal sensitivity was found to be weaker in mothers in the extended family (Crittenden and Claussen, 2000). Bárrig-Jó et al. (2016) found lower maternal sensitivity in a study conducted in Colombia, Uruguay and Peru with a group of $68.75 \%$ living in extended families. However, in our country, Seven and Ogelman (Seven \& Ogelman, 2012) examined the attachment stability of children in large and nuclear families. Although there was no significant difference in the study, it was found that the children in the nuclear family showed higher attachment stability than the children growing up in the extended family.

Despite the intensive research on adult attachment in Turkey, there are few studies on attachment of infants and children. However, research on maternal sensitivity has started in the last few years and few studies have yet been found. In addition, the form of maternal sensitivity in Turkish society and its status in family structures is not known yet in our country. The aim of this study is to investigate the interactions of mothers and their children between the ages of 30 and 42 months in the context of maternal sensitivity in their own homes and in a semi-structured play process. For this purpose, the following questions were sought:

I. How is the sensitivity cycle between a 30-42 month old child and their mother living in a large and nuclear family?

II. What is the mutual emotional exchange between the child and the mother?

III. What is the bilateral cooperation between the child and her mother?

\section{METHOD}

\section{Research Model}

Qualitative research is a type of research where qualitative data collection techniques such as observation, interview and document analysis are used, and a qualitative process is carried out to present perceptions and events in a realistic and holistic way in the natural environment (Yıldırım \& Şimşek, 2000). In this qualitative research, embedded multi-case research, which is a type of case study, was used (Yin, 2003). In 
this study, the grounded multi-case study was chosen to determine the basic behavior patterns in the mother-child interaction.

\section{Working group}

Mother-child couples participated in the study were determined based on criterion sampling among purposeful sampling methods used in qualitative research. In a research, observation units may consist of persons, events, objects or situations of a specific nature. In such a case, the units that meet the criteria determined for the sample are taken into sampling. In this study, the criterion was chosen as the sampling method in order to express the present situation best.

The participants of the study were volunteers for a total of 16 people: 8 mothers and 8 children, 4 girls and 4 boys, participated in the study. In the extended family of 4 mothers, 2 girls and 2 boys; 4 mothers, 2 daughters and 2 boys are in the nuclear family. The ages of children are between 31-38 months. Mothers are not working. Mothers are usually primary school graduates. Families are generally seen to have low incomes. The ages of the mothers were between 26-37 years. When the number of siblings of the children were examined, it was seen that 5 of them had 3 siblings and the others had less siblings.

\section{Data Collection Tools}

\section{Mother Child Observation Form}

In order to determine the interaction behaviors that will determine the sensitivity between mother and child during the observation process, the related literature was examined. In this context, the observation behavior list related to the formation of the sensitivity cycle that shapes the maternal sensitivity has been prepared (Juffer et al., 2008). The observation behavior list prepared was sent to 5 experts and expert opinions were received and the necessary arrangements were made and the form was finalized.

\section{Mother Child Information Form}

The mother-child information form was prepared by examining the literature on the factors affecting the sensitivity in order to better identify the child and the mother (Juffer et al., 2008; Yorgason, 2015) and family type.

\section{Data Collection}

Game activity was carried out using a standard 4-color play dough which was structured in the natural environment related to observation, which was fixed for all mother-child couples participating in the study. Application time is 10 minutes. Play dough mold is not used. The application was carried out in the houses where the mother-child couples feel most comfortable. The researcher positioned the camera at a point that would not catch the child's attention, but could clearly record mother-child behavior. During the observation process, the researcher was in the same environment but did not intervene in any way.

Game applications were made between August 1 - August 30, 2017. Necessary permissions were obtained from the families before the application.

\section{Data Processing and Analysis}

In this research, descriptive-interpretive data analysis was used. In this type of analysis, the data is reduced, put in a certain order, the data is selected and comments are made. In this type of analysis, appropriate interpretations are given on descriptive narratives (Ekiz, 2007). In this study, the data were examined, categories were tabulated and results were written and interpreted.

The video recordings to be obtained as a result of observation were encoded by 2 encoders and the data were generated. 


\section{FINDINGS}

Findings of the Sensitivity Cycle

Graph 1: Sensitivity Cycle for Extended Family

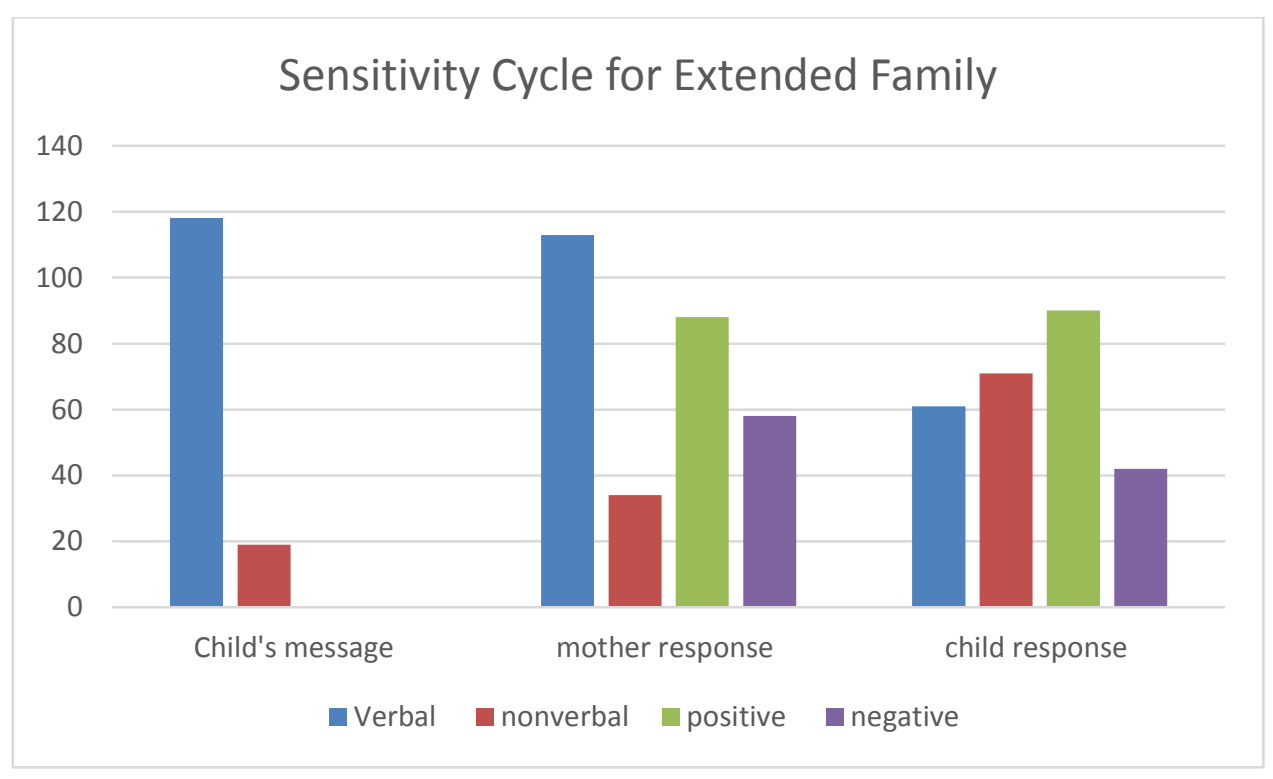

When the graph 1 is examined, it is seen that the pairs of mothers and children in the extended family send the children's messages more verbally in the sensitivity cycles, whereas the mothers' reactions are more verbal, but the negative reactions are higher. It is seen that children's reactions are more negative than mother responses and nonverbal responses exhibit more than verbal responses.

\section{Graph 2: Sensitivity Cycle for Nuclear Family}

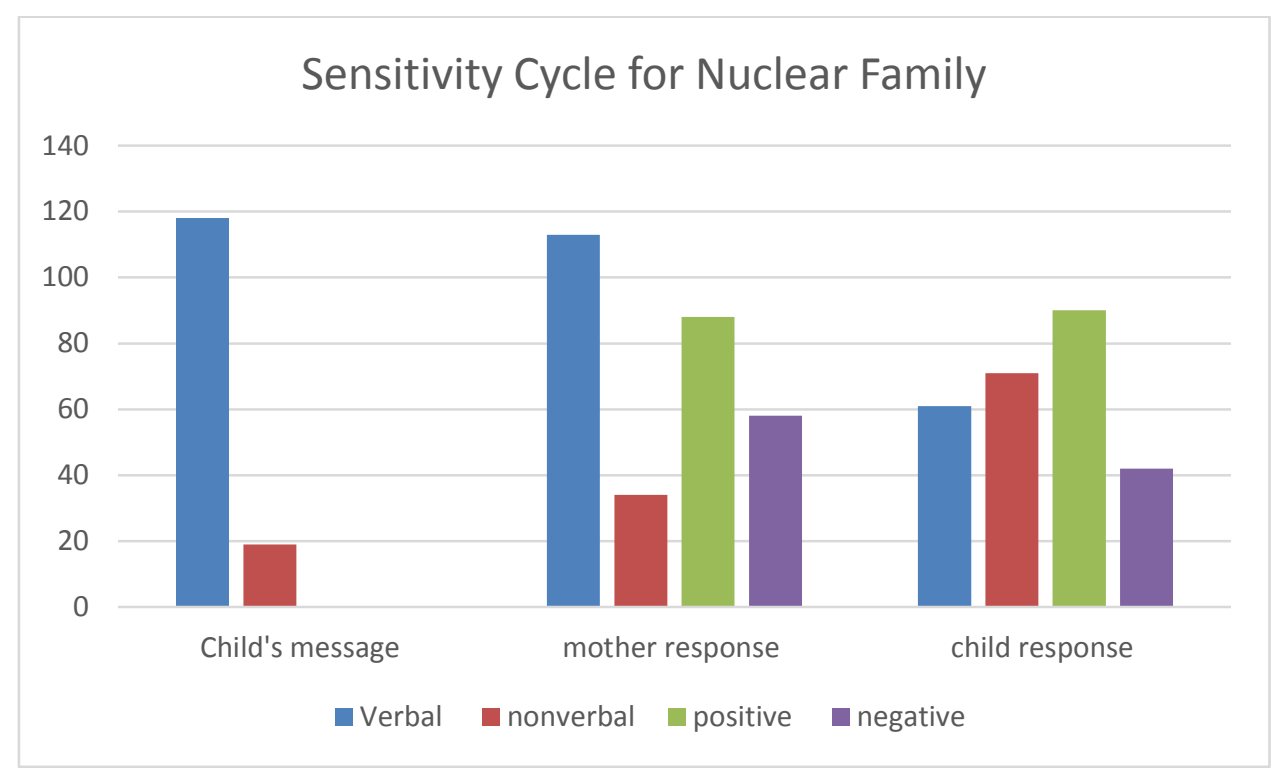

When the graph 2 is examined, it is seen that the pairs of mother and child couples in the family tend to send their children's messages more verbally in the sensitivity cycles, however the mothers' reactions are more verbal and positive reactions are more. It is seen that children's responses are more positive than mother responses and nonverbal responses exhibit more than verbal responses.

In both the extended family and the nuclear family, it was observed that children generally send their messages by verbal ways. It is seen that only a child (C1) in an extended family avoided verbal messages, and even hesitated to speak to the mother and sent her messages nonverbally. It was observed 
that the children in the nuclear family started a more frequent cycle of sensitivity by sending more messages in the game than the children in the extended family.

Apart from A1, mothers in the extended family often gave negative reactions to children's messages; on the contrary, it was observed that mothers in the nuclear family mostly responded positively to the messages of children except that A5.

One of the important findings of the study is related to the child's response to the mother's response in the sensitivity cycle. When the child's reactions are examined, there is a parallel with the positive or negative reactions of the mother both in the extended family and in the nuclear family. However, it was observed that mothers who showed unresponsive behaviors in response to the message of the child in the extended family were unresponsive towards their mothers, whereas children in the nuclear family did not show unresponsive behaviors in response to the mothers' unresponsiveness. This may be related to the fact that mothers often react negatively to the messages of children in the extended family, whereas mothers often respond positively to the messages of children in the nuclear family.

When the positive-negative reactions of the mothers were compared to the positive-negative reactions of the children, it was observed that apart from one of the mothers in the extended family (A1), the others showed more negative reactions, whereas the children also showed negative reactions. It was observed that the mother of the mother who had a positive response in the extended family had more negative reactions. In the nuclear family, except for one mother (A5), it was observed that the positive responses of the other mothers were higher whereas the positive responses of the children were higher. 
Table 1: Sensitivity Cycle Behavior Table

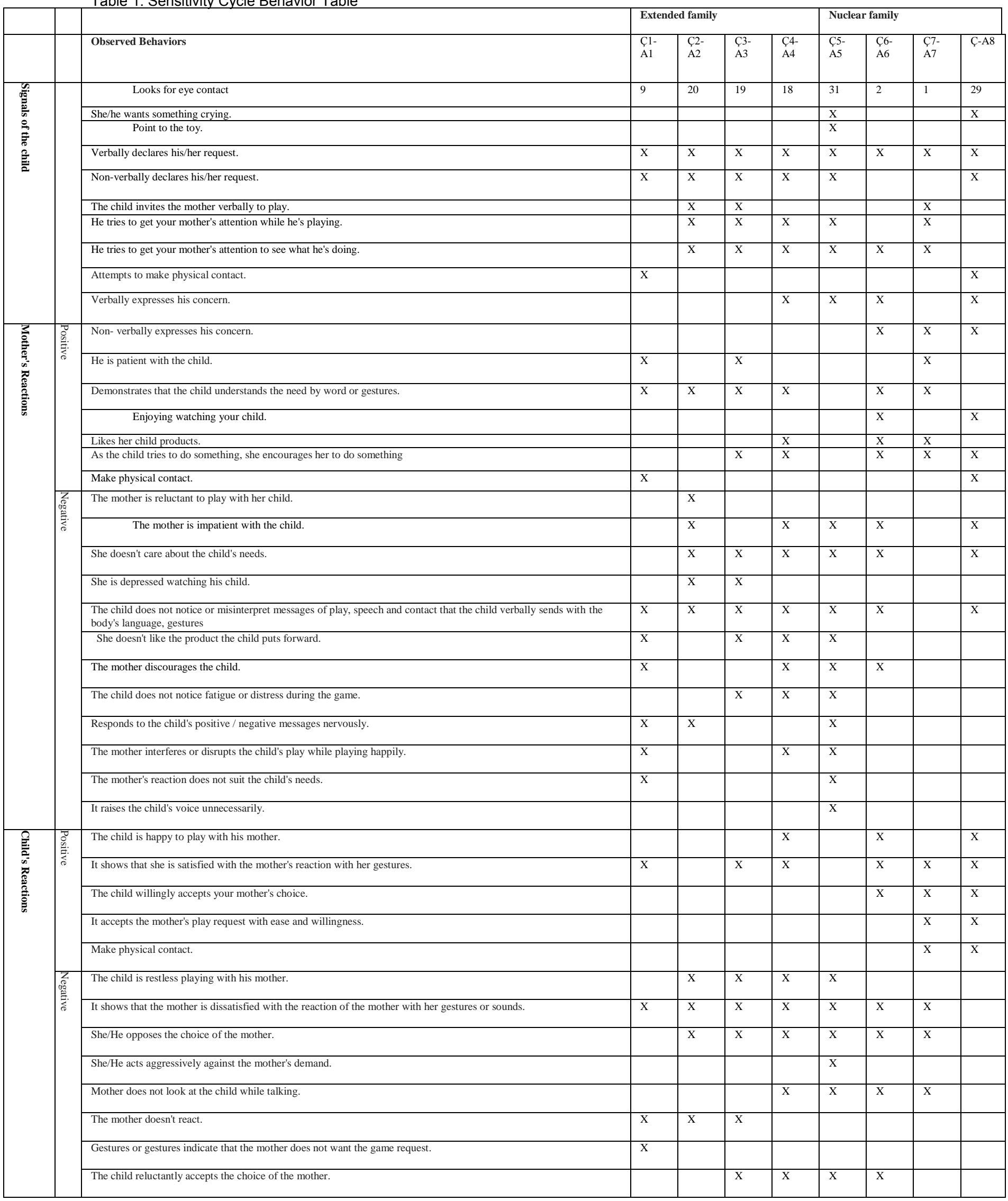


As shown in Table 1, physical contact deprivation was observed in maternal-child couples living in both extended and nuclear families. Only A8-Ç8 had both willing physical contact. In A1-Ç1, the mother kissed the child and asked her child to do so. The child was afraid to kiss his mother. The mother did not try to repair this situation. In A5, it was seen that physical contact was negatively effected by pushing, pulling and holding the child by the arm.

In the extended family, all mothers' behaviors of children disliked verbally or non-verbally were observed. These behaviors were verbally discouraging the child and expressing that he did not like the product of the child by means of body language, gestures and facial expressions. Such behaviors were not observed in nuclear family mothers. On the other hand, only one mother from the nuclear and extended families observed behaviors like her child's product in A4 and A6.

All mothers in both extended and nuclear families have at least one child's behavior of not understanding or ignoring messages sent by children. All mothers, except one mother in the large and nuclear family A1 and A7, took a reckless attitude towards the needs of their children.

In the research, it was observed that mothers in both extended and nuclear families mostly showed impatient attitudes towards their children; the children either reacted verbally to the mothers or accepted the mother's choice. One of the important findings of the study is that two of the children in the nuclear family used C5 and C8 to cry when sending messages. From time to time, these children cried their wishes. However, in a large family mother, she was found to be susceptible to the child, followed by depressed behavior.

\section{Findings of Emotion Sharing}

The level of the ability of mothers to perceive positive and negative facial expressions of their children is the most important indicator of sensory sensitivity (Donovan et al., 2007). This ability was examined by eye contact between mother-child pairs and the mother's attempts to look at the child's face. The form of eye contact seen in two mother-child pairs is remarkable. One of them is A5-Ç5. This motherchild pair is the second mother-child pair that makes the most eye contact. However, the eye contacts established started with the mother's initiative. In other words, the child constantly cares for the mother and expects the mother to play with her, and the mother plays according to her own agenda and tries to teach the child something. The mother takes care of the child whenever she wants to, especially when she asks questions. Eye contact occurred only at this time. The mother's effort to understand the child's feelings was not observed. The other mother-child pair is A7-Ç7. If the eye contact is in the form of starting, the opposite is the case. The mother is constantly looking at the child's face, but the eye contact has been observed to occur only when the child is looking at the mother. The mother is trying to understand the child's feelings, humorous situations and laughing behaviors have been seen between mother and child many times. In Q3, it was seen that the mother looked at her mother's face to check her emotions throughout the game. Noticing that his mother laughed in two places, the child suddenly laughed, but when the mother did not see a reaction, the child did not continue the laughing reaction by leaving it halfway and returned to the game.

When we look at the eye contact and other situations related to the mother's attempts to look at the child's face, the most common eye contact and looking at the child's face started with the attempts of both mother and child in A8-Ç8. In fact, the mother guessed that her child would be happy and slowly took the play dough out of the box and looked at her child to see the joy of her child. It is seen that A8 predicts and follows the emotions that the child will have beyond his / her current emotions.

Differences in emotion sharing between large and nuclear families were observed in the study. Although emotion sharing was rare in both family types, the tendency of mothers to hide their emotions was determined in the extended family. However, it has been observed that mother and child couples rarely resort to supportive factors such as physical contact and eye contact, while others do not. On the other hand, shy attitudes and crying behavior were observed in children and mothers. Shy attitudes were mostly observed in nuclear family children in Q1, Q5, Q8 and to a lesser extent Q6 and in extended family mothers $\mathrm{A} 2$ and A3. These mothers were smiling by turning their heads sideways against their children's reactions. It appears that these mothers are reluctant to share their happiness with their children. Crying behavior was 
found in Q5 and Q8 in nuclear family children. While crying behavior in Q5 was caused by anger against the mother's reactions, crying behavior in Q8 was that she felt inadequate and asked her mother for help.

One of the important findings related to emotion is that all boys in both extended families and nuclear families are trying to make their mothers happy. Ç2 raised his hands to make his mother happy in the face of his mother's misbehaving, and showed "we play like this" and repeated this several times when he realized that his mother had a slight smile. Ç3 constantly asked "what is this?" Style questions in order to keep her mother happy in the face of her mother's dejected attitude and when she smiled lightly during the game, she wanted to make her happy by smiling. When he noticed that his mother had dived in several parts of the game, he made jokes to make his mother laugh. Ç8, on the other hand, laughs intensely at her mother throughout the game, smiles, says that she loves her mother and makes her mother happy. On the other hand, no such effort was observed in girls.

Another finding related to emotion sharing is that the sharing of emotions of mother-child couples in the extended family is very rare. On the other hand, it is seen that emotion sharing is rare in the nuclear family. In the extended family, it is observed that only the A4-Q4 couple share emotions, albeit rarely. In the nuclear family, no emotion sharing was observed in the A5-Ç5 mother-child couple. It was observed that emotion sharing between mothers and their children was very rare in both family types.

In the extended family, two of the mothers were reluctant to play with their children in A2 and A3, and were found to be unhappy watching their children. In the extended family Ç1, it was observed that she was reluctant and shy against playing with the mother and even showed non-speaking behavior with the mother.

\section{Findings on Coordination and Cooperation}

Co-ordination and cooperation are almost non-existent in all maternal-child couples in the extended family. While the coordination and cooperation behaviors were negligible in the A5-Ç5 mother-child couple in the nuclear family, it was observed that the other mother-child couples in the nuclear family acted mutually in harmony despite some breaks and forming little products together. Nevertheless, it can be said that the coordination and cooperation behaviors of mothers have little place in the whole play.

In the extended family, A4 and A5-A8 in the nuclear family played the game according to their own agendas, and the children were often unable to plan or realize their plans. Mothers consistently responded negatively to children's attempts to play. Towards the end of the game, C5 showed crying behavior to participate in the game. On the other hand, Q2, Q3 (extended family) and Q7 (nuclear family) acted according to their own agenda during the game. While moving according to the agenda of A7 children, it was observed that mothers avoid making plans in A2 and A3 in the extended family.

In the sensitivity cycle, it was observed that mothers and children who mostly reacted negatively in coordination and cooperation behaviors. It is another factor that disrupts coordination and cooperation that all mothers experience breaks from time to time following the game. On the other hand, in all mothers except A7, the behavior of preventing the child from following the plan and giving negative response to the message of cooperation was observed at least once.

During the play process, it was observed that the children first tried to get their attention, then entertained them in the face of preventive and neutral attitudes of the mothers, and they showed crying and protest behaviors. Indeed, this situation is seen in A5.

Mutual regulation behaviors based on forming a common product during the play were observed only in two of the mother-child pairs. It was observed that the mother and child planned together and produced a product they made together. This situation is seen as a birthday celebration by making a birthday cake in the A6-Ç6 couple in the nuclear family, while it is seen that A7-Ç7 couple playing by making cars. In the other mother-child couples, no mutual regulation behavior was observed. Although mutual regulation behaviors were generally weak, it was observed that two of the mother-child couples in nuclear families had mutual regulation-related behaviors. 


\section{RESULT, DISCUSSION, AND SUGGESTIONS}

In the study, it was seen that both the extended family and the nuclear family generally sent their messages verbally. It was observed that the children in the nuclear family started a more frequent cycle of sensitivity by sending more messages in the game than the children in the extended family. Research has shown that children's verbal communication differs from culture to culture, and that mothers tend to communicate verbal messages and children's age and language acquisition (Beebe \& Lachmann, 2013; Hsu \& Lavelli, 2005). In this study, 30-42 months old children were studied. These children develop normal language skills. It is seen that children in nuclear families send more messages than those in extended families to form a more frequent cycle of sensitivity. Indeed (Seven \& Ogelman, 2012), it was determined that children living in nuclear families had higher attachment scores.

While it was observed that mothers who showed unresponsive behaviors in response to the message of the child in the extended family, their children behaved unresponsively towards their mothers, whereas children in the nuclear family did not show unresponsive behaviors in response to the mothers' unresponsiveness. This may be related to the fact that mothers often react negatively to the messages of children in the extended family, whereas mothers often respond positively to the messages of children in the nuclear family. The unresponsiveness behaviors of mothers were similar to the results of Akgün and Yeşilyaprak (2011) in their research conducted with 18 mothers with 4-5 age group children in order to evaluate the mothers' verbal expressions in mother-child play interaction.

There are many studies showing that positive responses of mothers in nuclear family contribute to secure attachment (Juffer et al., 2008). It is thought that the negative reactions to the child's signals, especially in the extended family, will adversely affect the child's attachment. This finding was parallel to the finding by Seven and Ogelman (2012) that the attachment levels of the extended family type children were lower than the children who grew up in the nuclear family.

Lack of physical contact was observed in mother-child couples living in both extended and nuclear families. Samples-Steele (2011) reported that physical contact and touch have the effect of reducing negative reactions. However, Kerns and Barth (1995) have suggested that the frequency of physical contact is an important factor in secure attachment. In this study, it was seen that the mothers and children in the study group did not make or avoid physical contact. This poses a risk for maternal sensitivity.

All mothers in both extended and nuclear families have at least one child's behavior of not understanding or ignoring messages sent by children. This shows that all mothers have more or less problems in sensory perception in mother-child interaction. In other words, it can be said that sensory sensitivity, defined as the level of the mother's sensitivity to the child's signals at the sensory level, is seen as problematic in the mothers participating in the study (Donovan et al., 2007). In the first stage of sensory sensitivity, mothers did not notice their children's messages; The unconcerned manners also indicate that the second stage is problematic.

One of the important findings of the study is that two of the children in the nuclear family used C5 and C8 to cry when sending messages. From time to time, these children cried their wishes. However, in a large family mother, she was found to be susceptible to the child, followed by depressed behavior. Shaw, Keenan \& Vondra (1994) argue that mothers fail to respond to children's signals, unsuccessful timing of the child's message, and low synchronization cause aggressive or disruptive behavior at 3 years of age. When the child reactions in the findings of the study are examined, behaviors such as opposition to mother, protesting mother and crying are seen. The findings of this study are consistent with that of Shaw, Keenan \& Vondra (1994).

It is seen that A8 predicts and follows the emotions that the child will have beyond his / her current emotions. This is in line with Biringen's (2000) parents' ability to perceive their children's emotional signals. Accordingly, it is understood that A8 has this ability by correctly predicting and behaving according to the emotions of the child.

Differences in emotion sharing were observed between the extended and nuclear families. Although emotion sharing was rare in both family types, the tendency of mothers to hide their emotions was determined in the extended family. Güler, Uzun, Boztaş, and Aydoğan, (2001), in order to determine the physical and emotional abuse and neglect behaviors of mothers at home, $81.1 \%$ of mothers showed that they did not show their loved ones to their children. They found similar findings in 2018 at İlhan Ildız \& Seven. 
These findings are similar to our study and it may be thought that mothers might have avoided sharing their happiness with their children.

Another finding related to emotion sharing is that the sharing of emotions of mother-child couples in the extended family is very rare. However, it is seen that emotion sharing is rare in the nuclear family. Emotional availability was stated by Biringen (2000) as the ability to perceive emotional expressions. The results of the research indicate that there may be some obstacles for mothers to express their feelings. It is thought that this may be caused by some cultural practices and beliefs in Anatolia. Ahioğlu-Lindberg, (2012) states that the emotional transmission of parents during the Ottoman and Republican periods was limited. However, he also stated that parents had the belief that "if love is manifested, children will be spoiled and that their behavior is shaped in this direction. In this study, all three mothers in the extended family type stated that in accordance with the traditional rules in the family, they were limited to show love, care and care to their children in the home environment. It is thought that these beliefs and practices have an effect on the mothers' inability to form unity of emotion, children's inability to recognize emotional expressions and hiding their emotional reactions to their children. Further research is needed to better understand this situation.

Co-ordination and co-operation are negligible in all mother-child couples in the extended family and in a mother-child couple in the nuclear family. The other couple in the nuclear family were found to be quite weak. This can be explained by poor synchrony between mother and child (Nicole Renick Thomson, Erin A. Kennedy, 2011).

As a result of the study, it is understood that the sensitive consciousness expressed by Meins et al (2012). It can be said that low sensitive awareness is an important indication that children's coordination and cooperation needs are not adequately addressed.

In all mothers, efforts were made to teach the child something. Teaching efforts seen in mothers are similar to the findings of Akgün and Yeşilyaprak, (2011), that mothers have teaching anxiety and use information expressions intensively. The teaching of mothers can be seen as an action in accordance with Vygotsky's (1978) convergent field theory as a natural tendency supported by Cohn \& Elmore, (1988), Dunham \& Dunham (1995), Tarabulsy, Tessier, \& Kappas (1996). However, some mothers' attempts to teach children above the level of development of children have had a detrimental effect on the interaction process for children.

During the play process, it was observed that the children first tried to get their attention, then entertained them in the face of preventive and neutral attitudes of the mothers, and they showed crying and protest behaviors. This supports the idea that negative behaviors will increase when there is no positive effect suggested by Tronick (1989) and the broken coordination is not tried to be repaired. However, according to Grossman, Bretherton, Waters, \& Grossman (2016), when the child sends a play invitation message, the child may react to distress and anger if the mother does not notice or misunderstand. When the child does not get the result he wants, he will continue to send new messages to restore the interaction, depending on the capacity to regulate, and try to establish balance. It can be said that the attention, entertaining effort, crying and protest behaviors in this research are efforts to repair the interaction by sending messages in different ways according to the capacities of children.

The most common family type in the Ottoman period was the extended family. In the Republican period, the nuclear family became the most common type of family first in cities and then in the countryside (Ahioğlu-Lindberg, 2012). However, some nuclear families who have migrated to rural areas and cities have largely maintained their extended family functions (Nacak, Yağmurlu, Durgel, and Van De Vijver, 2011). All of the mothers in this study who live in both extended and nuclear families come from extended families. Although mothers living in extended families exhibited more negative behaviors in terms of sensitivity than mothers in nuclear families, similar characteristics were observed in terms of emotional accessibility, coordination and cooperation behaviors. In terms of hiding emotions for the mother, lack of physical contact and eye contact, working together for the purpose, deficiencies and problems were observed in mothers from both family types. This supports the idea that the mother's own internal working model is transmitted (Holmes, 1993, 2009, 2014; P. Holmes and Farnfield, 2014). Traditional care practices and pattern behaviors in the extended family are thought to be effective in the formation of this model. Therefore, it is thought that stereotypical behavior and traditional practices have an effect on the behavior of mothers towards their children in the transition from extended family to nuclear family. 
In this study, only, the sensitivity of the mother in the play environment was examined. Maternal sensitivity during daily routines and other activities can be investigated in future studies. On the other hand, the effects of cultural practices on maternal sensitivity can be observed in more detail. According to the results of the research, the following can be suggested:

- In order for mothers to become aware of their children's emotions, supportive activities should be organized by the related institutions within the scope of sensory sensitivity.

- Since more problematic behaviors related to maternal sensitivity have been identified in the extended family structure, projects should be prepared and implemented within the Ministry of Family Social Policies in order to improve the sensitivity of extended families.

- Parents should make more eye contact and positive physical contact with their children. Traditional games based on theme need to be brought to the agenda again for this purpose.

- The negative reactions of mothers to their children's signals and reactions and the reasons for their unresponsiveness should be examined in the context of interactive synchronicity.

- Attachment theory and cultural studies should be conducted on mothers' behaviors such as showing their feelings and avoiding physical contact.

- Social stereotypes and practices that prevent or limit love and emotional transfer in traditional Turkish families need to be identified through research.

- This study was conducted to determine the sensitivity behaviors of mothers whose children were between 30-42 months. Similar studies of mothers of younger and older children will contribute to the field.

- Due to the fact that the Turkish family structure comes from a large family and the families of this family structure to a considerable extent today, further studies can be conducted on the effect of this family type on the social and emotional development of children.

- Further research should be made on which interaction characteristics seen in the extended family continue in the nuclear family in the types of families that have experienced a transition from extended family to nuclear family due to cultural transfer.

\section{REFERENCES}

Ahioğlu-Lindberg, E. N. (2012). Çocuk yetiştirme açisindan türkiye'de çocukluğun tarihi. Pamukkale Üniversitesi Ĕ̆itim Fakültesi Dergisi, 31(31), 41-52.

Ainsworth, M.D.S., Bell, S.M., \& Stayton, D. J. (1974). Infant-mother attachment and development: "Socialization" as a product of reciprocal responsiveness to signals. In M. P. Richards (Ed.), The integration of a child into a social world. London: Cambridge University Press.

Ainsworth, M. D. . D. S., Blehar, M. . C., Waters, E., \& Wall, S. (1978). Patterns of attachment: A Psychological study of the strange situation. In Journal of the American Academy of Religion (Vol. 52). https://doi.org/10.1093/jaarel/52.2.411-a

Akgün, E., \& Yeşilyaprak, B. (2011). Anne çocuk oyun etkileşiminde niteliksel boyut: Annelerin sözel ifadelerinin değerlendirilmesi. Hacettepe Üniversitesi Ĕ̆gitim Fakültesi Dergisi, 40, 11-20.

Alink, L. R. A., Mesman, J., Van Zeijl, J., Stolk, M. N., Juffer, F., Bakermans-Kranenburg, M. J., ... Koot, H. M. (2009). Maternal sensitivity moderates the relation between negative discipline and aggression in early childhood. Social Development, 18(1), 99-120. https://doi.org/10.1111/j.1467-9507.2008.00478.x

Bárrig-Jó, P., Nóblega, M., Del Prado, J. N., Conde, G., Carbonell, O. A., \& De Litvan, M. A. (2016). Attachment Representations and Maternal Sensitivity in Low Socioeconomic Status Mothers. International Journal of Psychological Studies, 8(3), 202. https://doi.org/10.5539/ijps.v8n3p202

Beebe, B., \& Lachmann, F. M. (2013). The origins of attachment: Infant research and adult treatment. The Origins of Attachment: Infant Research and Adult Treatment, 1-231. https://doi.org/10.4324/9781315858067

Biringen, Z. (2000). Emotional availability: Conceptualization and research findings. The American Journal of Orthopsychiatry, 70(1), 104-114. https://doi.org/10.1037/h0087711

Bowlby, J. (1969). Attachment and loss: Attachment. In Attachment (Vol. 1). 
https://doi.org/10.1177/000306518403200125

Cassidy, J. (2016). The nature of the child's ties. In Hanbook of Attachment Theory, Research, and Clinical Applications (third edition) (pp. 3-24). Retrieved from http://ezproxy.muni.cz/login?url=http://search.ebscohost.com/login.aspx?direct=true\&AuthType=ip,co okie, uid\&db=psyh\&AN=2008-13837-025\&lang=cs\&site=eds-live\&scope=site

Cohn, J. F., \& Elmore, M. (1988). Effect of contingent changes in mothers' affective expression on the organization of behavior in 3-month-old infants. Infant Behavior and Development, 11(4), 493-505. https://doi.org/10.1016/0163-6383(88)90008-2

Crittenden, P. M., \& Claussen, A. H. (2000). The organization of attachment relationships. In The Organization of Attachment Relationships. https://doi.org/10.1002/casp.861

Donovan, W., Leavitt, L., Taylor, N., \& Broder, J. (2007). Maternal sensory sensitivity, mother-infant 9-month interaction, infant attachment status: Predictors of mother-toddler interaction at 24 months. In Infant Behavior and Development (Vol. 30). https://doi.org/10.1016/j.infbeh.2006.10.002

Dunham, P. J., \& Dunham, F. (1995). Optimal social structures and adaptive infant development. In Joint Attention - Its Origins and Role in Development (pp. 159-188). Retrieved from file://Users/Domingo/Documents/Literature/E_Lit/

Eagle, M. N. (2013). Attachment and psychoanalysis: Theory, research, and clinical implications. New York: The Guilford Press.

Ekiz, D. (2007). Bilimsel araştirma yöntemleri. Ankara: Lisans Yayıncılık.

Grossman, K. E., Bretherton, I., Waters, E., \& Grossman, K. (2016). Maternal sensitivity: Mary ainsworth's enduring influence on attachment. Routledge.

Güler, N., Uzun, S., Boztaş, Z., \& Aydoğan, S. (2001). Anneleri tarafından çocuklara uygulanan duygusal ve fiziksel istismar/ihmal davranışı ve bunu etkileyen faktörler. C.Ü. Tip Fakültesi Derg, 24(3), 128-134.

Holmes, J. (1993). John bowlby and attachment theory. In John Bowlby and Attachment Theory. https://doi.org/10.4324/9781315879772

Holmes, J. (2009). Some implications of attachment research for psychotherapeutic practice. Hellenic Journal of Psychology, Vol. 6, pp. 310-333. Retrieved from http://search.ebscohost.com/login.aspx?direct=true\&db=psyh\&AN=2010-03679-005\&site=ehostlive\%5Cnj.a.holmes@btinternet.com\%5Cnhttp://search.ebscohost.com/login.aspx?direct=true\&db=psyh \&AN=2010-03679-005\&site=ehost-live\%5Cnj.a.holmes@btinternet.com

Holmes, J. (2014). John bowlby and attachment theory. In John Bowlby and Attachment Theory. https://doi.org/10.4324/9781315879772

Holmes, P., \& Farnfield, S. (2014). The Routledge handbook of attachment: theory. pages $\mathrm{cm}$. https://doi.org/10.4324/9781315762098.ch1

Hsu, H. C., \& Lavelli, M. (2005). Perceived and observed parenting behavior in American and Italian firsttime mothers across the first 3 months. Infant Behavior and Development, 28(4), 503-518. https://doi.org/10.1016/j.infbeh.2005.09.001

İlhan Ildız, G., \& Seven, S. (2018). 30 İle 45 Yaşlari Arasindaki Yetişkinlerin Sevgiyi Alma Ve Aktarma Biçimleri Üzerine Nitel Bir Çalişma. ULEAD 2018 Annual Congress, 21.

Juffer, F., Bakermans-Kranenburg, M., \& van Ijzendoorn, M. H. (2008). Methods of the video- feedback programs to promote positive parenting alone, with sensitive discipline, and with representational attachment discussions. In F. Juffer, M. Bakermans-Kranenburg, \& M. H. van Ijzendoorn (Eds.), Promoting Positive Parenting An Attachment-Based Intervention (pp. 11-21). New York: Lawrence Erlbaum Associates.

Kerns, K. A., \& Barth, J. M. (1995). Attachment and play: Convergence across components of parent-child relationships and their relations to peer competence. Journal of Social and Personal Relationships, 12(2), 243-260. https://doi.org/10.1177/0265407595122006

Main, M., \& Solomon, J. (1990). Procedures for identifying infants as disorganised/disoriented during the Ainsworth Strange Situation. In Greenberg T., D. Cicchetti, \& E. M. Cummings (Eds.), Attachment in the preschool years (University, pp. 121-160). Chicago.

Meins, E., Fernyhough, C., de Rosnay, M., Arnott, B., Leekam, S. R., \& Turner, M. (2012). Mind-mindedness as a multidimensional construct: Appropriate and nonattuned mind-related comments independently predict infant-mother attachment in a socially diverse sample. Infancy, 17(4), 393-415. 
https://doi.org/10.1111/j.1532-7078.2011.00087.x

Metin Orta, İ. (2010). The effects of dispositional anger, effortful control and maternal responsiveness on Turkish preschoolers' emotion regulation. Koç University.

Nacak, M., Yağmurlu, B., Durgel, E., \& Van De Vijver, F. (2011). Metropol ve Anadolu'da ebeveynlik: Biliş ve davranişlarda şehrin ve eğitim düzeyinin rolü. Turk Psikoloji Dergisi, 26(67), 85-100.

Nicole Renick Thomson, Erin A. Kennedy, and J. E. K. (2011). Attachment formation between deaf infants and their primary caregivers: Is being deaf a risk factor for insecure attachment? In D. H. Zand \& P. J. Katherine (Eds.), Resilience in Deaf Children Adaptation Through Emerging Adulthood (pp. 26-64). London: Springer.

Samples-Steele, C. R. (2011). Adult attachment as a predictor of touch attitudes and touch behavior in romantic relatonships. Degree of Bachelor of Arts With Honors in Psychology from Tha University of Michigan.

Seven, S., \& Ogelman, H. G. (2012). Attachment stability in children aged 6 to 9 years in extended and nuclear families. Early Education \& Development, 23(5), 766-780. https://doi.org/10.1080/10409289.2011.607362

Shaw, D. S., Keenan, K., \& Vondra, J. I. (1994). Developmental precursors of externalizing behavior: Ages 1 to 3. Developmental Psychology, 30(3), 355-364. https://doi.org/10.1037//0012-1649.30.3.355

Smith, P. B., \& Pederson, D. R. (1988). Maternal sensitivity and patterns of infant-mother attachment. Child Development, 59(4), 1097-1101. https://doi.org/10.2307/1130276

Tarabulsy, G. M., Tessier, R., \& Kappas, a. (1996). Contingency detection and the contingent organization of behavior in interactions: implications for socioemotional development in infancy. Psychological Bulletin, 120(1), 25-41. https://doi.org/10.1037/0033-2909.120.1.25

Tronick, E. Z. (1989). Emotions and emotional communication in infants. American Psychologist, 44(2), 112 119. https://doi.org/10.1037/0003-066X.44.2.112

Vereijken, C. M. J. L., \& Riksen-Walraven, J. M. (1997). Maternal sensitivity and infant attachment security in Japan: A longitudinal study. International Journal of Behavioral Development, 21(1), 35-50. https://doi.org/10.1080/016502597384974

Vygotsky, L. S. (1978). Interaction between learning and development. Mind and Society, pp. 79-91. https://doi.org/10.1016/S0006-3495(96)79572-3

Wallin, D. J. (2007). Attachment in Psychotherapy. New york: The Guilford Press.

Yin, R. K. (2003). Case study research design and methods. Third Edition, Applied Social Research Methods Series, Vol 5. London: Sage Publications.

Yıldırım, A., \& Şimşek, H. (2000). Sosyal bilimlerde nitel araştirma yöntemleri. Ankara: Seçkin Yayıncılık.

Yorgason, L. A. T. (2015). Effectiveness of Mary Ainsworth's maternal sensitivity scale with four-week-old infants. The University of Montana. 